[Bull. Agr. Chem. Soc. Japan, Vol, 20, No. 3, p. 157 158, 1956]

\title{
An Acyl Migration in Acetohalogenoglucosamines
}

Sir :

In the fall of last year Micheel et al.1) reported that the acetobromoglucosamine $(3,4,6$ tri-O-acetyl-2-acetylamino-2-deoxy-D-glucosyl bromide) (Ia) described in the literature is actually $\alpha$-1,3,4,6-tetra-O-acetyl-D-glucosamine hydrobromide (IIa), and an interpretation that in the usual method2) of preparation for Ia it is IIa that is produced directly but not Ia has been presented. We had been engaged in some synthetic works starting from acetobromoglucosamine and had arrived independently at the same conclusion that the so-called Ia was IIa, m.p. $210-230^{\circ},[\alpha]_{\mathrm{D}}^{13}+$ $129^{\circ}$ (c 1, water), Anal. Calcd. for $\mathrm{C}_{14} \mathrm{H}_{22} \mathrm{O}_{9}$ $\mathrm{NBr}$ : C, 39.26; H, 5.18; N, 3.27. Found: C, $39.44 ; \mathrm{H}, 5.41 ; \mathrm{N}, 3.21$, which was converted for identification into $\alpha$-pentaacetyl-D-glucosamine, ${ }^{3)}$ m.p. and mixed m.p. $135^{\circ}$, and $\alpha$ 1,3,4,6-tetra-O-acetyl-2-N-(o-carboxybenzoyl)D-glucosamine, m.p. $176^{\circ}$, Anal. Calcd. for $\mathrm{C}_{22} \mathrm{H}_{25} \mathrm{O}_{12} \mathrm{~N}: \mathrm{C}, 53.33 ; \mathrm{H}, 5.09 ; \mathrm{N}, 2.83$. Found: $\mathrm{C}, 53.05 ; \mathrm{H}, 5.09 ; \mathrm{N}, 2.88$. Our interperation ${ }^{4)}$ of the result was that the $\mathrm{N}$-acetyl group in Ia migrated after debromination at $\mathrm{C}-1$ to form IIa during the preparation.

Confirmative evidence of this acyl migration was obtained with an analogue of $\mathrm{Ia}$, acetochloroglucosamine (3,4,6-tri-O-acetyl-2acetylamino-2-deoxy-D-glucosyl chloride)(Ib). Crystalline $\mathrm{Ib}^{5)}$ was relatively stable upon standing in dryness. It was converted into

1) F. Micheel, F.-P. van de Kamp and H. Wulf, Chem. Ber., 88, 2011 (1955).

2) R.C.G. Moggridge and A. Neuberger, J. Chsm. Soc., 1938 , 745.

3) Y. Inouye, K. Onodera, S Kitaoka and S. Hirano, J. Am. Cbem. Soc. ia press.

4) Report at the Annual Meeting of the Agr. Chem. Soc. Japan, March 30, 1956, Tokyo.

5) B. R, Baker, J.P. Joseph, R. E. Schaub and J. H. Williams, J. Org. Chem., 19, 1786 (1954). $\alpha-1,3,4,6-t e t r a-O$-acetyl-D-glucosamine hydrochloride (IIb), m.p. $185^{\circ},[\alpha]_{\mathrm{p}}^{\prime \prime}+140^{\circ}$ (c 1, water); Anal. Calcd. for $\mathrm{C}_{14} \mathrm{H}_{22} \mathrm{O}_{9} \mathrm{NCl}$ : C, $43.79 ; \mathrm{H}, 5.78 ; \mathrm{N}, 3.65$. Found : C, $44.05 ; \mathrm{H}$, $5.77 ; \mathrm{N}, 3.41$, partially upon refluxing for one hour in moist chloroform, and completely upon that in acid-containing moist chloroform. These results support our view with evidence that the $\mathrm{N} \rightarrow \mathrm{O}$ acetyl migration in acetohalogenoglucosamine is catalyzed by moisture and acid. After examination of reported acyl migrations in amino alcohols, we present the following mechanism for the acetyl migration in acetohalogenoglucosamine.

Starting from this reaction mechanism, we succeeded to prepare $\beta$-methyl-D-glucosaminide tetraacetate, ${ }^{6)}$ m.p. $160^{\circ},[\alpha]_{\mathrm{b}}^{18}-24^{\circ}$ (c l, $\mathrm{MeOH})$; Anal. Calcd. for $\mathrm{C}_{15} \mathrm{H}_{23} \mathrm{O}_{9} \mathrm{~N}: \mathrm{C}$, 49.86; H, 6.41; N, 3.89. Found: C, 49.86 ; , $6.42 ; \mathrm{N}, 3.88$, and $\beta$ - $p$-toluidine-N-D-glucosaminide tetraacetate, $\left.{ }^{7}\right)$ m.p. $183^{\circ},\left[\alpha_{-D}^{-18}-2^{\circ}\right.$ ( c 1 , $\mathrm{MeOH})$, Anal. Calcd. for $\mathrm{C}_{32} \mathrm{H}_{28} \mathrm{O}_{8} \mathrm{~N}_{2}: \mathrm{C}$, $57.79 ; \mathrm{H}, 6.46 ; \mathrm{N}, 6.41$; Found : $\mathrm{C}, 57.45 ; \mathrm{H}$, $6.45 ; \mathrm{N}, 6.38$, by the use of fresh chloroform extract of the reaction mixture ${ }^{2)}$ of pentaacetylD-glucosamine and $\mathrm{HBr}$-acetic acid, the fact showing that Ia is formed to be active in the glycosidation by the Koenigs-Knorr reaction. Micheel et al.1) and earlier investigators ${ }^{2,5)}$ failed to prepare glucosaminides by this reaction and two teams ${ }^{6,7)}$ of investigators who succeeded did not give detailed description on their Ia. It was noted in oursyntheses that silver oxide catalyzed the O-glucosidation from Ia, thus disproving the specific activity of mercury cyanide in this reaction as proposed by Kuhn and Kirschenlohr.6)

6) R. Kuhn and W. Kirschenlohr, Cbem. Ber., 86, 1331 (1953).

7) (a) A. Bertho and D. Koziollek, Chem. Ber., 87, 934 (1954); (b) $\mathrm{Y}$. Inouye, K. Onodera and S. Kitaoka, J. Agr. Chem. Soc. Jaban 29, 908 (1955). 


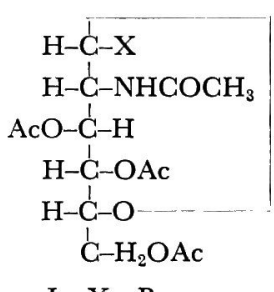

Ia $\mathrm{X}=\mathrm{Br}$

Ib $\mathrm{X}=\mathrm{Cl}$

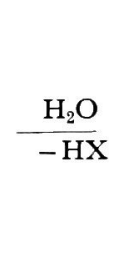

$$
\begin{gathered}
\mathrm{HO}-\stackrel{+}{\mathrm{C}}-\mathrm{H} \\
\mathrm{H}-{\stackrel{\mathrm{C}}{\mathrm{C}}-\mathrm{NHCOCH}_{3}}^{-\mathrm{COCH}}
\end{gathered}
$$
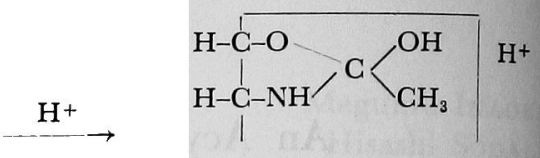

\section{$+$}<smiles>CC1(O)COCC1[18OH]</smiles><smiles>[X]CC</smiles>

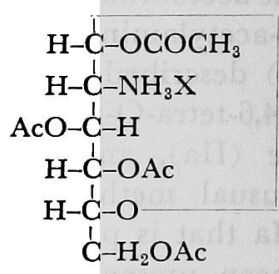

IIa $\mathrm{X}=\mathrm{Br}$

IIb $\mathrm{X}=\mathrm{Cl}$
Attempted crystallization of the actual Ia from the above fresh chloroform extract has hitherto led to the isolation of IIa. Ia seems to undergo very rapid acyl migration in the extract.

Synthesis of some amino-disaccharides from the chloroform extract of Ia is under way, and will be published later along with the detailed description of the work outlined above.

Yoshiyuki INOUYE,

Shozaburo KITAOKA,

Hideo OchiaI

Biochemical Laboratory, College of Agriculture, Kyoto University, Kyoto 